\title{
CULTURA VISUAL Y REPRESENTACIÓN TEXTUAL: LA IMAGEN DE LOS PUEBLOS AMERICANOS A TRAVÉS DE LA ENCYCLOPEDIE DES VOYAGES DE JACQUES GRASSET SAINT SAUVEUR (1796)
}

\author{
ALBERTO GULLÓN ABAO | UNIVERSIDAD DE CÁDIZ \\ ORCID iD: 0000-000 1-6005-0980
}

ARTURO MORGADO GARCÍA | UNIVERSIDAD DE CÁDIZ

ORCID iD: 0000-0003-3849-8062

A tres grandes profesionales $\gamma$ tres fantásticas personas: Manuel Bustos Rodríguez,

Juan Ramón Cirici Narváez y Fernando Pérez Mulet

\begin{abstract}
RESUMEN
A través de la obra de Grasset Saint Sauveur, Encyclopédie des Voyages, se pretende ofrecer una panorámica de la visión textual y visual de los pueblos americanos a finales del siglo XVIII, visión influida por una serie de tópicos muy concretos.

PALABRAS CLAVE

Ilustración, siglo XVIII, viajes, América, cultura visual.

\section{VISUAL CULTURE AND TEXTUAL REPRESENTATION: THE IMAGE OF AMERICAN PEOPLE THROUGH THE ENCYCLOPEDIE DES VOYAGES OF JACQUES GRASSET SAINT SAUVEUR (1796)}

\begin{abstract}
Through the work of Grasset Saint Sauveur, Encyclopédie des Voyages, we want to offer an overview of the textual and visual vision of the American peoples in the late eighteenth century, a vision influenced by very specific topics.
\end{abstract}

\section{KEYWORDS}

Enlightenment, 18th century, America, travel, visual culture. 


\section{EL AUTOR Y SU OBRA}

$\mathrm{P}$ odríamos aplicarle a Jacques Grasset Saint Sauveur, autor de la obra Encyclopedie des vopages ${ }^{1}$, la máxima de que hay quien mira y hay quien ve, pero incluso el que ve lo hace a través de un prisma que tamiza la realidad o la reinterpreta en función de lo aprendido en su propia cultura y hace llegar la imagen a los receptores, en numerosas ocasiones, con un fuerte carácter analógico para su comprensión. Con este trabajo pretendemos analizar cómo a través de la visión de Grasset se ve y se construye la imagen de los pueblos americanos en Europa, que son modelos de una realidad, independientemente del grado de verosimilitud ${ }^{2}$.

Nuestro autor, Grasset Saint Sauveur, es poco conocido, y son los coleccionistas y amantes de las impresiones los que siguen disfrutando hoy día de las numerosas ilustraciones de enciclopedias que realizó a lo largo de su vida; sin embargo, podemos decir de él que fue uno de los intermediarios culturales habidos en la Ilustración europea, mostrándonos, en su caso, otras gentes, otras culturas y otros mundos. No pretendemos valorar las posibles nociones de verdad o ficción que nos encontramos en su producción, nos enfrentamos aquí con un artista que copia, imita, reproduce, yuxtapone y entreteje elementos completos de la realidad, una cierta realidad que él genera y que le es útil a la sociedad donde se desenvuelve, pero sin duda los escritos y las imágenes que realiza se convierten en el vehículo perfecto para compartir conocimientos ancestrales y la difusión de las nuevas ideas.

Jacques Grasset nació en Montreal el 15 de abril de 1757 en el seno de una familia de comerciantes y es difícil de definir ya que ejerció de diplomático, viajero, diseñador, grabador, escritor, compilador, editor, actor, etc. Su padre, André Grasset de Saint-Sauveur, embarcó para Canadá en 1747 como secretario del gobernador de la Nueva Francia pero fue apresado por una escuadra inglesa frente a las costas españolas y fue liberado tras el tratado de Aquisgrán en 1748, por lo que no pudo llegar a Quebec ni tomar posesión de su cargo hasta el año siguiente. Se casó en segundas nupcias con Marie-Joseph Quesnel, madre de Jacques,

1 Se utiliza al respecto la obra de GRASSET SAINT SAUVEUR, Jacques, Encyclopédie des voyages. Contenant l'abregé historique des moeurs, usages, habitudes domestiques, religions, fétes, supplices, funérailles, sciences, arts, et commerce de tous les peuples. Amérique, 1796. Empleamos el ejemplar existente en la Bibliotheque de la ville de Lyon que es el digitalizado por Google Books. La estructura de la obra responde claramente a cuadernillos sueltos que han sido encuadernados con posterioridad, por lo que no hay una paginación correlativa. Por tal motivo, las referencias hacen alusión siempre al capítulo correspondiente.

2 Un ejemplo en RAMÍREZ ALVARADO, María del Mar. Construir una imagen. Visión europea del indígena americano. Sevilla, 2001. 
e hija de un acaudalado comerciante de Montreal que había participado en los negocios de su padre desde una temprana edad. Es a partir de ese momento cuando la pareja centra su actividad económica en las operaciones comerciales con los indios, este hecho, aunque Jacques fuera un infante, nos hace reflexionar sobre la posibilidad de algunos encuentros reales con los indígenas de la zona, o al menos con la obtención de información en las charlas de sus padres o admiración de los productos que llegaban al almacén que debieron enervar su imaginación y quizás su interés por otras culturas ${ }^{3}$. En 1761 André fue acusado, junto al Intendente François Bigot y otros oficiales civiles, judiciales y militares de la Nueva Francia de conflicto de intereses y abusos en el ejercicio de sus funciones ${ }^{4}$, y en 1764 , ante el cariz que estaba tomando la investigación, decide viajar a París junto a su mujer y sus cinco hijos; siendo a la postre desestimado su caso por falta de pruebas. En 1772, fue nombrado cónsul en Trieste y en el archipiélago veneciano de Zante, siendo su situación financiera caótica, como lo demuestra el hecho de que tuvo que dejar su familia a cargo de una comunidad religiosa, así como algunas cartas de su mujer en petición de auxilio económico. Muere completamente arruinado en 1792.

Parece ser que Grasset, inspirado por el ejemplo de su progenitor, decidió seguir sus pasos en la diplomacia siendo Vice-Cónsul de Francia en Hungría, en el Levante, y en el Cairo, aunque esto último no está aún claro. Lo que sí es evidente es el interés político que Francia tenía por aquellas tierras como se puso de manifiesto en las campañas que desarrolló Napoleón en Italia que tuvo como colofón el tratado de Campo Formio en donde obtiene de Venecia las islas del Levante, entre otras Corfú y Zante, y posteriormente las campañas de Egipto (1798-1801) que influye en un incremento del interés literario y cultural del denominado "orientalismo" ${ }^{5}$. Esta política expansionista ya se vislumbra en la obra de Grasset en donde hace una reflexión sobre las injusticias sociales, especialmente en África, aunque también ataca al "barbarismo" de estos pueblos a los que hay que "ayudar desde Europa”.

Grasset es un polígrafo, lo que era muy habitual en los autores finidieciochescos, los cuales, debido a su precaria situación económica (lo que la historiografía anglosajona denomina

\footnotetext{
3 Debemos señalar que una de las obras más apreciadas de Jacques Grasset es Moeurs, loix et trajes de sauvages du Canada , Chez les principaux Libraires du Royaume, 18?, $4^{\circ}$. TURBIA, Chantal , "Jacques Grasset de Saint-Sauveur y el vestuario de los indios de Canadá “, Siglo XVIII Ficción, Vol. 23 Iss. 4, art. 3, 2011.

4 CÔTÉ, André. L`affaire du Canada. Cap-aux-Diamants: la Revue d’ Histoire du Québec, 83, 2005, p. 10-14. http://id.erudit. org/iderudit/7048ac.

5 BRENARD, Andrés. Jacques Grasset de Saint-Sauveur, Ou la mobilité culturelle au temps des Lumières. Interfaces Brasil /Canadá, 8, Río Grande, 2008. Sobre el orientalismo remitimos a la obra clásica de SAID, Edward. Orientalismo. Madrid: Ediciones Libertarias, 1982.
} 
Grub Street) debían estar continuamente publicando, pudiendo remitirnos a los casos de Restif de la Bretonne en Francia o de Pedro Estala y Antonio Marqués y Espejo en España. Y vivirá en una época de transformaciones, puesto que va a pasar por el Antiguo Régimen, la Revolución y el Imperio napoleónico, transformaciones que no sólo inciden en los cambios políticos sino también en los culturales como las artes o la literatura, siendo precisamente en ese periodo tan convulso cuando genera su gran producción ${ }^{6}$. En 1784 lo encontramos en París, trabajando en un atlas etnográfico de varios volúmenes en donde se reflejan las principales naciones de la tierra, cuyos textos son de Jean François Cornu, que le reportó pingües beneficios. Ya iniciada la Revolución participó activamente en la "Conspiración de los Iguales" que sostenía que la igualdad real sólo llegaría con una revolución social, pero el Directorio al que pretendían derrocar estaba perfectamente informado y los cabecillas de la Conspiración fueron apresados. Durante estos años reeditó sus obras etnográficas, a la vez que publicó libros sobre trajes, uniformes militares y de funcionarios de la República; asimismo trabajo en relatos que podíamos denominar libertinos y un grupo de obras de inspiración moral o filosófica. Siguiendo con su azarosa vida, entre 1802 y 1804 estuvo trabajando con una compañía de comediantes y posteriormente participó como grabador en una publicación botánica de Joseph Roques, miembro de la sociedad científica francesa especializado en botánica que tuvo un importante éxito en varias obras ${ }^{7}$. Jacques Grasset murió en mayo de 1810 en París.

\section{LA IMAGEN “DEL OTRO”}

La obra que hemos trabajado es la Encyclopédie des vopages contenant l'historique abrégé de moeurs, Habitudes domestiques, religión, fêtes, Supplices, funérailles, de tous les peuples: Complette et la colección de leurs habillemens Civils, militaires, religieux et dignitaires, dessinés d'apres la naturaleza, tumbas avec soin et colorés à l'Aquarelle (Deroy, París, 1796, en 5 volúmenes de 4 ${ }^{\circ}$ con 432 tableros). Es interesante la lectura de su Discurso preliminar, donde señala cuales son los destinatarios de la obra, a saber, los jóvenes (que aprenderán con placer la Geografía y la Historia), los viajeros, los comerciantes o especuladores, las mujeres (que encontrarán una fuente inagotable de novedades, como las vestimentas ligeras del Medio Oriente, las plumas de los americanos, las perlas de los africanos o los diamantes de los asiáticos) y

6 BERNARD, Andrés. De Montréal aux Échelles du Levant. Jacques Grasset de Saint-Sauveur (1757-1810). Cahiers de la Mediterranee, 75. 2007, págs 133-143

7 Phytographie Médicale, ornée de figures coloriées de grandeur naturelle, ou l'on expose l'Histoire des Poisons tirés du régne végétal, et les movens de reméder a leurs délérères, avec des observations sur les propriétés et les usages des plantes héroiques. París, 1821-1825. 2 Volúmenes. 
lo que el autor llama los amateurs, que podrán hallar en las costumbres y en las figuras de todos los pueblos la influencia del clima y los caracteres de cada uno de ellos.

Grasset ejemplifica en imágenes a los pueblos relacionados con el continente americano y recrea, en una rara colección de láminas coloreadas, sus respectivas vestimentas, acompañadas de algunos objetos y adornos que podríamos denominar "identificativos" de sus culturas. Siguiendo la tradición europea, estas imágenes reflejan no sólo "realidades culturales" ajenas o extrañas, sino que ayudaban a reafirmar la propia identidad, diferenciando o categorizando a los indígenas como algo distinto ${ }^{8}$. Tan fuerte es la huella creada por la imagen que se generó a lo largo de la modernidad, que aún hoy día persiste la idea de lo indio, sabiendo perfectamente que ese concepto es una proyección europea sobre una realidad multicultural y multiétnica que abarca un espacio concreto que es América. Es difícil escribir sobre una unidad cuando la riqueza cultural supera con creces a la de la propia Europa, pero seríamos injustos y tendríamos falta de rigor científico si considerásemos a lo europeo también como una unidad, y no tuviéramos en cuenta las diferencias culturales entre los distintos pueblos que formaban "Europa", aunque también es cierto la existencia de una cierta tradición común y una identidad que los largos siglos de contacto habían creado.

En opinión de Carla Oliveira, la iconografía europea sobre el Nuevo Mundo (figura 1) es extremadamente profusa en ejemplos de visiones peliculiares sobre un universo que se mostraba incógnito al conquistador europeo, y en este contexto las imágenes surgidas a partir de las idealizaciones sobre un mundo tan distante, dicen mucho más sobre el medio y la cultura en que se produjeron que sobre aquello que pretendían representar ${ }^{9}$. Como afirma Alfredo Jiménez Núñez, la imagen no es la cosa, no es la realidad, sino una representación que individual o colectivamente hacemos, producimos, en cierto modo fabricamos, de la realidad. La imagen, por lo tanto, es un producto cultural, ya sea individual o colectivo, que se tamiza por un filtro llamado cultura con toda su escala de valores, creencias o percepciones. Además, ese producto de la cultura se transmite y se transforma dentro del seno de esa propia sociedad en función de épocas y factores que la condicionan ${ }^{10}$.

8 La visión sobre el indígena en Europa fue una “...réplica de la autocomprensión del europeo, frente a lo cual se vio al indio como algo diferente de lo europeo y de lo que se entendió por cultura europea". PIETSCHMANN, Horst. Visión del indio e historia latinoamericana. Imagen del indio en la Europa Moderna, Sevilla, 1990.

9 OLIVEIRA, Carla Mary S.. A América alegorizada. Imagens e Visoes do Novo Mundo na Iconografia Europeia dos Séculos XVI a XVIII. Editora da UFPB, 2014, p. 21.

10 JIMÉNEZ NUÑEZ, Alfredo. Imagen y culturas: consideraciones desde la antropología ante la visión del indio americano. Imagen del indio en la Europa Moderna, Sevilla, 1990. 
La imagen de lo indio se construye así a partir de diferentes modelos del pensamiento europeo que recogen y aglutinan diferentes realidades que existían en el continente americano. Nace del choque entre ambos mundos y se va articulando en función de los intereses que subyacen a favor de establecer un tipo de relación de sometimiento, en el amplio sentido de la palabra (económico, político, cultural...) de las poblaciones del Nuevo Mundo ${ }^{1}$. Es así, como afirma Peter Mason, que América pierde su especificidad etnológica, incluso geográfica, para entrar en la problemática de la alteridad ${ }^{12}$. En el aspecto etnológico, el hecho de describir a un ser humano implicaba un cierto problema ya que por una parte había que ubicar al otro en su propio mundo, y por otra, darle uniformidad a los humanos, uniformidad en la que no todos los europeos estaban de acuerdo a principios del XVI, centrándose su descripción más en el comportamiento que en sus rasgos físicos ${ }^{13}$.

En el lenguaje la idea de lo diferente, de lo distinto, pasará por vocablos como salvajes, bárbaros o incluso inferiores para acercarnos posteriormente al "buen salvaje" o a lo "exótico". En ese cambio de percepción no sólo va a influir las corrientes culturales, sino también el conocimiento paulatino del Otro. Los fármacos, los nuevos productos, el desarrollo tecnológico de algunos pueblos, etc; hacen que se replantee en Europa la imagen y la actitud hacia el Otro, por supuesto sin llegar al revisionismo de la alteridad, entendida como la voluntad de fomentar un diálogo intercultural; sino más bien de un reconocimiento de algo distinto al que, en contadas ocasiones, hay que respetar o más concretamente salvaguardar como algo exótico en el mejor de los casos. No hay que olvidar que cualquier descripción de la época, incluso aquéllas que son más benévolas, incluye términos que señalaban a estos pueblos como bárbaros e incultos; así, el propio Grasset no dudaba en calificar a muchos de ellos simplemente como sauvages.

En el mundo del arte estas ideas van a tener su reflejo en una serie de imágenes relacionadas inicialmente con el barbarismo e incluso con el canibalismo y posteriormente de formas idealizadas y alegóricas en donde se plasma una cierta armonía en connivencia con la naturaleza (el mito del buen salvaje) ${ }^{14}$, pero siempre hay un reflejo de lo diferente que transforma la imagen en un modelo de exclusión de la comunidad de lo "europeo" ${ }^{15}$.

11 LAVALLÉ, Bernard. Del indio al criollo: evolución y transformación de una imagen colonial. Imagen del indio en la Europa Moderna, Sevilla, 1990, p. 319.

12 MASON, Peter. Reconstructing América. Representations of the Other. New York, 1990.

13 PAGDEN, Anthony. La caída del Hombre natural. El indio americano $\gamma$ los orígenes de la etnología comparativa. Madrid,1988.

14 Estamos ante un epifenómeno, "la idealización del bárbaro", "el mito del buen salvaje", que surge en la Antigüedad v que tiene una larga tradición que pasa por el Medievo y que va a continuar en la Edad Moderna. Dicho mito va a estar relacionado en la Edad Medía con los franciscanos y algunas herejías europeas que llegaron a proponer "...las excelencias de una vida sencilla $\gamma$ pobre, ... que la desnudez de los pueblos <<salvajes>> era una señal de la inocencia y la pureza." SEBASTIAN, Santiago. El indio desde la iconografía. Imagen del indio en la Europa Moderna. Sevilla, 1990. KÜGELGEN KROPFINGER, Helga von. El indio: ¿bárbaro y/o buen salvaje?. Imagen del indio en la Europa Moderna. Sevilla, 1990.

15 PIETSCHMANN, Horst, op.cit., p. 5. 


\section{Figura 1}

Frontispice de l’Amerique. Grasseut de Saint-Saveur, Encyclopédie des Voyages. Amérique

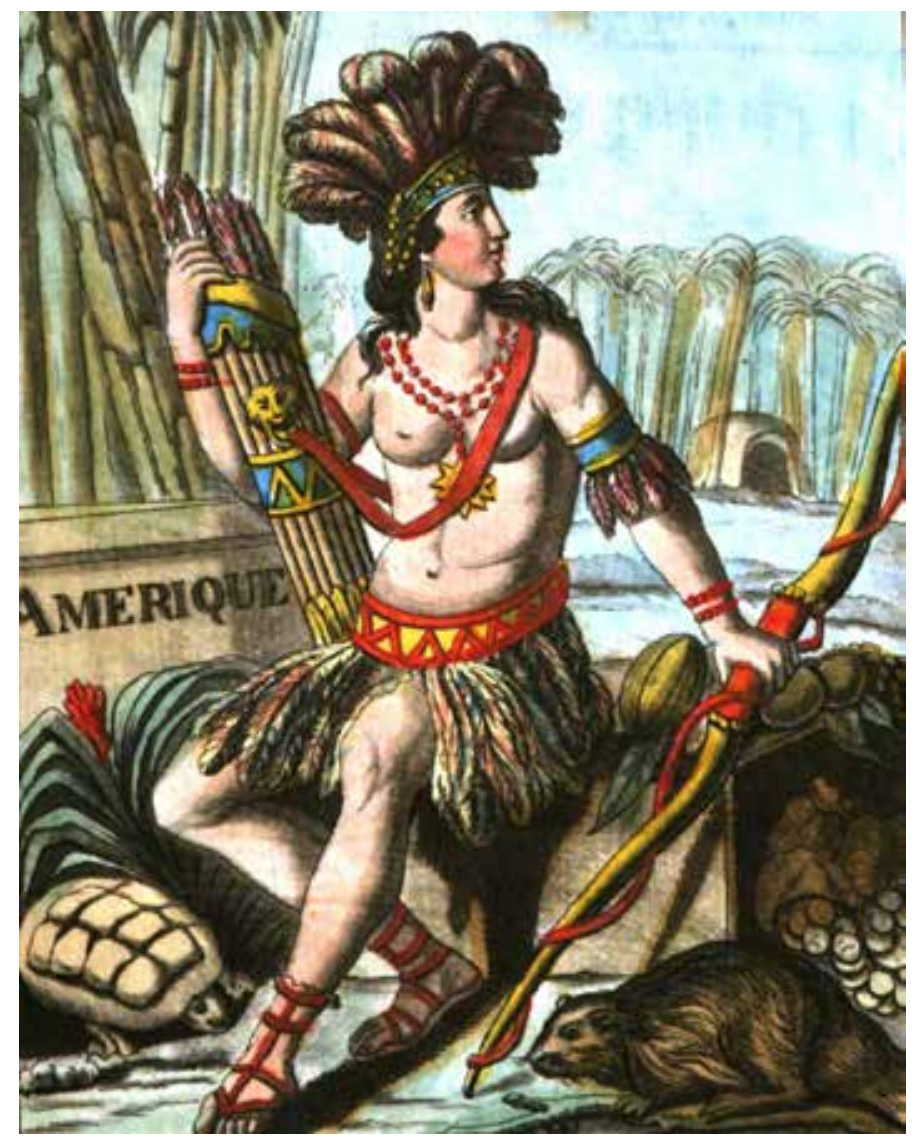

La imagen del indio se relacionará con la desnudez y la antropofagia, costumbres observadas en los tupinambaes brasileños, siendo comúnmente aplicados dichos rasgos a todos los pobladores del continente. Los españoles hicieron imágenes bien diferenciadas, pero no las publicaron debido al secretismo oficial de la corona ${ }^{16}$, por lo que son los modelos elaborados en ciudades italianas y Basilea los que triunfan en las ilustraciones de las primeras ediciones de las cartas Colombinas, y observamos cómo llama poderosamente la atención la práctica del canibalismo en obras como Wahrhaftige Historia und Beschriebung epner Landschafft der Wilden (1557), del luterano Hans Staden, Les singularitez de la France antarctique (1558), del francés André Thevet, o Histoire d'un voyage fait en la Terre du Bresil (1578)

16 García Saiz argumenta que la discreción que quería la corona, el recelo sobre los descubridores, el deseo de evitar críticas a la política indiana en especial a la de los indios, la identificación de América con tierras propias, como España, no algo exótico y la incapacidad de los artistas para interpretar en imágenes un mundo carente de tradición en su experiencia hizo que España no fuera el gran referente de la imagen del Indio en Europa. GARCíA SAIZ, Ma Concepción. La imagen del indio en el arte español del siglo de oro. Imagen del indio en la Europa Moderna. Sevilla, 1990, p. 418. 
del también francés Jean de Lery. Una segunda oleada iconográfica correspondería a los pobladores de la fallida colonia inglesa de Virginia, que ya aparece claramente esbozada en los grabados de Theodor de Bry que ilustraban el Briefe and True report of the new found land of Virginia (1590) de Thomas Harriot, y que responden más al ideal del buen salvaje, prestando una gran atención a detalles como el peinado, las joyas o la decoración corporal, reflejando, como no podía ser menos, las ideas europeas del momento sobre la belleza ${ }^{17}$. Todo este esfuerzo de representación se encuentra plenamente consolidado en la obra de Albert Eeckhout, que dedicará sus desvelos a la plasmación pictórica de los pobladores brasileños a mediados del siglo XVII. En su trabajo nos encontramos con una clara diferenciación de los diferentes tipos étnicos conseguida gracias a la indumentaria, el peinado, y otros atributos externos ${ }^{18}$, aunque ya a finales del siglo XVIII el color de la piel se convertiría en un poderoso factor de diferenciación, tal como han mostrado los estudios de Roxann wheeler ${ }^{19}$, unido a otros componentes, como la utilización o no de la barba, que en opinión de Londa Schiebinger constituye un poderoso factor de civilización ${ }^{20}$.

Es por lo tanto la Europa no española la que genera una imagen prototípica que posteriormente la exportará a América. Esa imagen recogida en mil y una obras que incluía al indio cubierto con un faldellín de plumas y adornado con objetos del mismo material, se introduce con tal fuerza en el arte americano que se convierte en el modelo para las imágenes de los indios no cristianizados empleada por los propios pintores coloniales ${ }^{21}$. Esta imagen con el transcurrir del tiempo se transformó en una alegoría que representaba al Continente Americano, con el añadido de algunos elementos como el cuerno de la abundancia o un pequeño monte en representación de Potosí; asimismo, reseñamos la aparición de animales propios como el tucán, que desde antaño representaba las áreas tropicales o selváticas, y posteriormente las llamas, armadillos o caimanes ${ }^{22}$.

Y fue de tal calibre el nuevo imaginario que se formó, y en el que participaría nuestro autor, que no sólo va a afectar a las corrientes culturales e intelectuales europeas, sino que hubo

\footnotetext{
17 BRIENEN, Rebecca. Visions of savage paradise. Albert Eckout, Court Painter in Colonial Dutch Brazil. Amsterdam: University Press, 2006, p. 22.

18 BRIENEN, Rebecca, op. cit., p. 75

19 Cfr. WHEELER, Roxann. The complexion of race. Categories of Difference in Eighteenth-Century British Culture. University of Philadelphia Press, 2000.

20 Cfr. SCHIEBINGER, Londa. Naturés Body: Gender in the Making of Modern Science. Boston: Beacon Press, 1993.

21 KÜGELGEN KROPFINGER, Helga von. op.cit.

22 Ibídem, p. 431.
} 
un proceso de autoidentificación de los propios pobladores, que a la postre asumieron esta visión como algo propio ${ }^{23}$. Todo ello muestra claramente que el tema de identidad, que está en continuo movimiento y se negocia casi a diario, no sólo atañe a la visión de los europeos, sino también a los propios representados.

\section{EL CONTEXTO: EL DEBATE SOBRE LA NATURALEZA AMERICANA}

Según los europeos del siglo XVIII, el continente americano estaba poblado por multitud de gentes distintas, procedentes tanto del propio continente, como de Europa (figura 2), como de África. En opinión del jesuita español Pedro Murillo Velarde, “Cuatro especies de gente son las que hoy habitan en las Indias. La 1. es de los naturales de ellas, que son los indios. La 2. de los españoles, qe las poblaron. La 3. de los hijos de èstos nacidos en Indias, que se llaman criollos. La 4. los negros, que se llevan de Africa" ${ }^{24}$. Pero sobre todos ellos pesaba una valoración negativa, que se extendía incluso a los de origen europeo: “En lo general del genio, costumbres, $\gamma$ modales, no igualan los hijos nacidos en Indias a sus padres, sino que declinan algo, $\gamma$ se suele decir que el padre que viene de España recoge, porque con su industria $\gamma$ trabajo hace el caudal. El hijo desperdicia, porque criado en aquella abundancia, $\gamma$ no sabiendo lo que cuesta el buscarlo, lo gasta sin reparar, y el nieto pide limosna, que él es fruto y la herencia que le deja el desperdicio de su padre" 25 .

Durante mucho tiempo esta pretendida inferioridad se achacó a las condiciones climatológicas del continente. Montesquieu en el capítulo XIV de El espíritu de las lejes (1748) enunciaba su conocida teoría de los climas, señalando cómo “Los pueblos de los países cálidos son temerosos como los viejos; los de los países fríos, temerarios como los jóvenes. Si no, fijándonos en las últimas guerras, en las que por tenerlas a la vista podemos descubrir ciertos detalles, observaremos que los pueblos del Norte no realizan en los países del Sur las mismas proezas que en su propio clima.... Haven los climas del Norte pueblos de pocos vicios, bastantes virtudes $\gamma$ mucha sinceridad $\gamma$ franqueza. A proximaos a los países del Sur, $\gamma$ creeréis que cada paso os aleja de la moralidad: las pasiones más vivas, multiplicarán la delincuencia. Ya en la zona templada son los pueblos

23 "La pintura de Bolívar abrazando a América sería una alegoría de la libertad. Este tipo de imagen utilizada por José de Figueroa también fue difundida ampliamente en medallas conmemorativas y monedas, fue una respuesta a las nuevas demandas. La alegoría de América realizada por Figueroa, probablemente fue inspirada en una litografía hecha a partir de una acuarela de la obra de Jacques Grasset.." CHICANGANA-BAYONA, Yobenj Aucardo. La india de la libertad: de las alegorías de América a las alegorías de la patria. Estudios de Filosofía Práctica e Historia de las Ideas. Vol. $13 n^{0}$ 1, Mendoza, julio 2011 / Artículos (17-28), p. 19.

24 MURILLO VELARDE, Pedro. Geographia Historica. T. IX, Madrid, 1752, p. 45.

25 MURILLO VELARDE, Pedro. Geographia Historica. T. IX, Madrid, 1752, p. 49. 


\section{ALBERTO GULLÓN ABAO ARTURO MORGADO GARCÍA}

inconstantes en sus usos, en sus vicios, hasta en sus virtudes, porque el clima tampoco tiene fijeza". Jorge Juan y Antonio de Ulloa, por su parte, también hicieron alusión a la inclemente naturaleza de algunas comarcas americanas, indicando cómo en Portobelo "no procreaban allí los animales de otros climas $y$ así las gallinas, que se introducían de Panamá o Cartagena, se esterilizaban luego que llegaban allí, $\gamma$ no ponían huevos $\gamma$ ho $\gamma$ sucede todavía, que la carne de vaca que se consume se lleva de Panamá en pie, $\gamma$ a poco tiempo de estad, se enflaquece tanto que no se puede comer...tampoco se ven crías de caballos, o burros, $\gamma$ todo esto confirma la opinión de que aquel temple es contrario para la generación de criaturas de otros temperamentos benignos" ${ }^{26}$.

Figura 2

“Espagnole de Quito" en Grasseut de Saint-Saveur, Encyclopédie des Voyages. Amérique

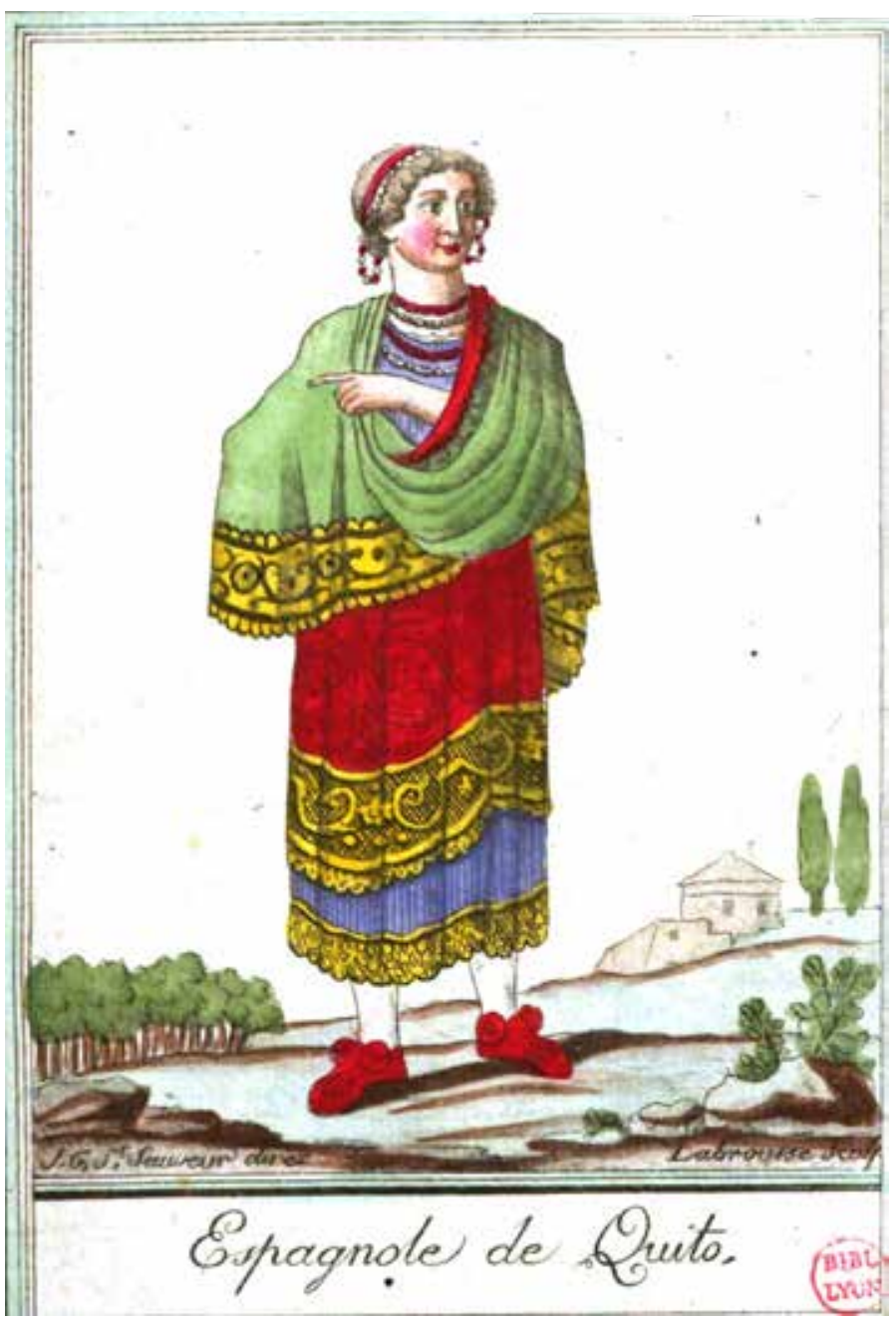

26 JUAN, Jorge, y ULLOA, Antonio de. Relación Histórica del Viaje a la América meridional. Primera parte, T I, p.127. 
Pero el gran debate sería inaugurado por la Historia natural de Buffon, que había señalado que las criaturas americanas eran menos activas, variadas y vigorosas que las del viejo Mundo. De este modo, los leones del Nuevo no serían de ninguna manera el mismo rey de los animales conocido en el viejo. No hay elefantes en América, y no se encuentra ningún animal similar, el único que se le podría comparar lejanamente es el tapir brasileño, cuyo tamaño es el de una mula pequeña. Tampoco hay jirafas, camellos, hipopótamos ni rinocerontes en América, y sus bestias más grandes serían más pequeñas que las europeas. Tal como lo presenta Gerbi ${ }^{27}$, la obra de Buffon es una clara afirmación del eurocentrismo en las ciencias de la naturaleza.

Estos puntos de vista serían popularizados por el prusiano Cornelis de Pauw en su Récherches Philosophiques sur les Américains (1771), en la que consideraba a los animales americanos monstruosos, poniendo como ejemplos al tapir y al oso hormiguero. En el clima americano los animales pierden la cola, los perros no ladran, la carne de vaca se deteriora y los órganos sexuales de los camellos sencillamente dejan de funcionar ${ }^{28}$. Por supuesto, lo mismo que observamos en las especies animales, también se aprecia en los seres humanos: si para Buffon los nativos (que no los criollos) estaban afectados por dicha degeneración, De Pauw considera que estos últimos también eran física e intelectualmente inferiores, y que los europeos trasladados a América se veían afectados por esas condiciones degenerativas.

Todos estos planteamientos se encuentran reflejados en la obra de Grasset, que se refiere a un escritor célebre que ha sostenido que los americanos eran una raza de hombres degenerados por la inclemencia del clima, y que los europeos que se establecen también se degeneran. Caracteriza a los indígenas americanos como indolentes y perezosos y resalta su pereza; asimismo afirma que no se ocupan del mañana, comen y bailan durante buena parte del día, y pasan el resto del tiempo durmiendo, teniendo poca memoria, señalando por causa, el tabaco que consumen. Asimismo, describe el cuerpo de los americanos como depilado, similar al de los eunucos; que ellos tienen leche o una especie de sustancia lactosa en sus mamas y que son poco ardientes en el amor.

En lo que se refiere a su cultura, remarca la poca industria de los pueblos americanos, incluso de los mexicanos y peruanos a los que achaca un especial desarrollo por el clima

27 GERBI, Antonello. La disputa del Nuevo Mundo. Historia de una polémica, 1750-1900. México: Fondo de Cultura Económica, 2a ed. corregida y aumentada, 1982.

28 NIETO OLARTE, Mauricio. Orden natural y orden social: ciencia y política en el Semanario del Nuevo Reino de Granada (1808-1810). Madrid: CSIC, 2007, pp. 202ss. 
templado que habitan. Remarca que los americanos no tienen registros ni saben leer ni escribir, y que si hay en el Nuevo Mundo hombres que saben hacerlo son venidos de Europa; para él, el americano natural no sabe nada, es un pueblo que no se puede aplicar a ninguna ciencia ni arte, e incluso llega a afirmar que en toda la extensión de América no ha aparecido un filósofo, un sabio, un artista u hombre de espíritu. Todo ello, según Grasset, es causado por la gran humedad de la atmósfera y las inundaciones que han viciado y depravado el temperamento de la especie humana en el Nuevo mundo desde la época de su invasión por navegantes venidos del antiguo.

\section{Figura 3}

“Negre \& Negresse de S. Domingue" en Grasseut de Saint-Saveur, Encyclopédie des Voyages. Amérique

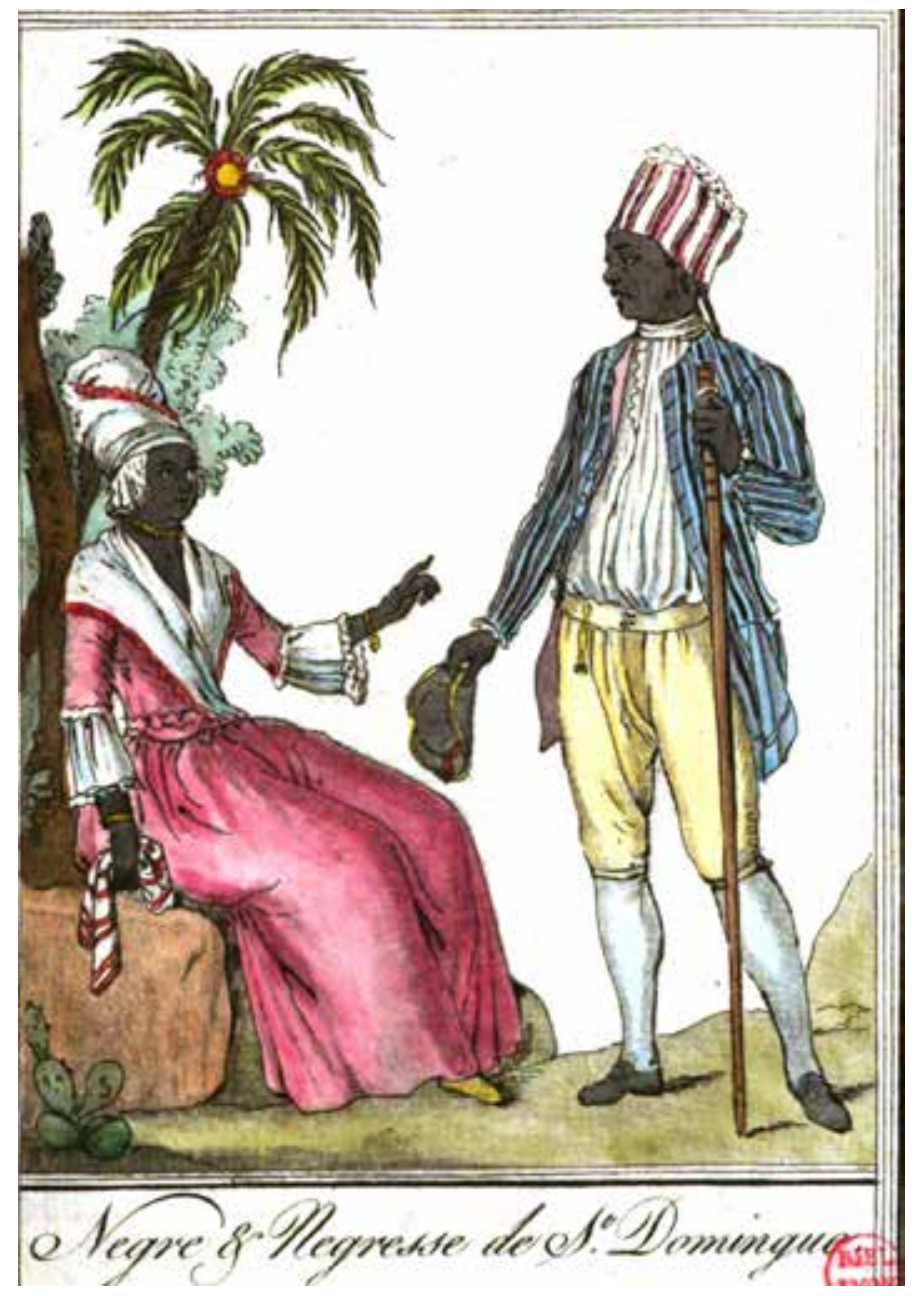

Jacques Grasset señala en su obra que uno de los lugares donde es más palpable esta degeneración es la isla de Santo Domingo (figura 3), en la que los europeos pierden la fuerza de 
su temperamento. Sus habitantes, se caracterizan por una indolencia extrema, una pereza que nada puede hacer cambiar, es el principio de su temperamento, enemigos del trabajo y no tienen ninguna inquietud; señala que después de haber bailado parte del día emplean el resto del tiempo durmiendo. Incapaces de malignidad, quizás sin espíritu y sin memoria, sin pasiones, no saben nada y no tienen ningún deseo por instruirse. Tienen la incontinencia mas inmoderada, no tienen ninguna ley que fije entre ellos el número de mujeres, solamente respetan el primer grado de sangre. Por las múltiples descripciones reseñadas podemos afirmar que el texto refleja ampliamente los planteamientos de Buffon sobre la naturaleza americana y condicionan fuertemente la representación de los pobladores del Nuevo Mundo que realiza Grasset.

\section{LA REPRESENTACIÓN TEXTUAL}

Hemos de destacar en la obra objeto de estudio que la selección geográfica es sumamente sesgada, centrándose fundamentalmente en tres ámbitos: las altas culturas del continente y sus sucesoras en la actualidad (México, Perú, Quito)(figura 4), los ámbitos de colonización francesa (Guayana, Santo Domingo, Acadia), y los pueblos del Pacífico recientemente descubiertos por los europeos (Patagonia, Tierra de Fuego, California, Nootka, bahía de Norton, Príncipe Guillermo, Oonalaska), correspondiendo la única excepción a los pobladores de la bahía de Hudson. Ni los pueblos relacionados con la colonización portuguesa ni con la expansión territorial británica tienen representación alguna.

La descripción de los habitantes americanos en la obra de Grasset está muy condicionada, en la forma y en el fondo, por las tecnologías descriptivas y las imágenes tópicas de los no europeos propias de finales del siglo XVIII. El humanismo reforzó la idea de que el testimonio ocular de los individuos que habían visitado los mundos lejanos era un hecho manifiesto, fiabilidad que se reforzaba o decrecía en función de la calidad e interés de los testigos y el lugar que ocupaban en dicha sociedad llena de privilegios corporativos y cuya erudición dependía del favor y patrocinio de los poderosos. Sin embargo, a partir de la segunda mitad del XVIII, la situación cambiará y se pondrá en tela de juicio las descripciones de los individuos que han visitado aquellos sitios, tanto en el sentido de la cualificación del informante como de la coherencia de los testimonios que aportase; así, Voltaire señalaba "...que no había que creer a cualquier escrito de historiador o no que fuese en contar de la naturaleza y del sentido común" 29.

29 CAÑIZARES ESGUERRA, Jorge. Cómo escribir la historia del Nuevo Mundo. México: FCE, 2007, p. 40. 
Por lo tanto, se podría afirmar que los relatos de viajes, que prácticamente habían sido dogma de fe con anterioridad, habían perdido parte de su crédito en el campo científico, pero eso no significó la desaparición de dichos libros, a los que el vulgo estaba aficionado al gustar de los relatos maravillosos. La aparición de ilustraciones en los libros de viajes seguramente tuvo que ver también con la precisión que se buscaba. Los textos podrían llevarnos a equívocos en función de los lectores, lo que seguramente generó una imagen de función aclaratoria en la obra, para ello, los nuevos "viajeros filósofos" tendrían que pintar o dibujar a los sujetos de esas nuevas tierras o al menos llevar a alguien que lo hiciera, con la esperanza de captar realidades que no llevaran a equívocos o fantasías. Poco a poco, los relatos de los viajeros filósofos se fueron imponiendo, y se pusieron en tela de juicio el valor de los primeros informes de los europeos.

En la Ilustración existía la preocupación por parte de los intelectuales de redescubrir el mundo por un viajero docto; que la información no llegara solo por los ojos de marineros, viajantes, comerciante o soldados, sino por gente cualificada de intelecto, pero sin los claros prejuicios de otros viajeros formados con anterioridad, como los misioneros; que dichos viajeros describiesen y explicasen las "culturas de los otros" desde la "cientificidad", y aunque se percibe claramente la influencia del tópico del carácter fabulador, falaz y falso de los relatos de viajes ${ }^{30}$, ya se vislumbra un conocimiento específico de elementos culturales y modos de vida de los pobladores. En sus láminas se observa un cierto interés cultural herencia desde luego de los viajeros utópicos que se preocupan por imitar o reproducir elementos complejos de una realidad, indiscutiblemente una realidad tamizada y adaptada que de alguna manera conecta los conocimientos anteriores con las nuevas ideas que se están produciendo en la Ilustración. Este es el resultado de la preocupación ilustrada, que potencia una determinada técnica literaria fundamentada en el hecho de juzgar los testimonios por su consistencia interna y no por la posición social o los conocimientos de los testigos ${ }^{31}$.

Ello a su vez requería la utilización de un estilo caracterizado por la claridad, la minuciosidad y la modestia, jugando un papel fundamental en la creación del mismo los trabajos de Robert Boyle en la segunda mitad del siglo XVII ${ }^{32}$. El siglo XVIII fue el momento en el que se

30 PIMENTEL IGEA, Juan. Impostores y testigos. Verosimilitud y relaciones de viajes.Testigos del mundo. Ciencia, literatura y viajes en la Ilustración. Madrid: Marcial Pons, 2003.

31 CAÑIZARES ESGUERRA, Jorge. Cómo escribir la historia. op.cit. pP. 37-38.

32 SHAPIN, Steven, y SCHAFFER, Simon. Leviathan and the air pump. Princeton U.P., 1985. Shapin ha reflexionado sobre estas cuestiones en multitud de ocasiones, pudiendo destacar su obra A social history of Truth, University of Chicago Press, 1994. 
origina una subdivisión de los puntos descriptivos, y no se puede comprender el sentido de esta división sin entender la relación entre el texto y la imagen. Si para Réaumur la imagen es un mero auxiliar de la descripción, porque transmiten simultáneamente información de la misma naturaleza, siendo seguido en sus afirmaciones por Perrault o Brisson; otros, como Adanson, la consideran un discurso científico serio, añadiendo que las descripciones deben ser cortas y versar sobre aquellos aspectos que el dibujo no puede reflejar, como la sustancia, la solidez, el suelo o el clima ${ }^{33}$. No obstante, desde finales del Siglo de las Luces habrá una fuerte reacción contra esta prosa desnuda y desprovista de metáforas, constituyendo el brillante estilo literario de Humboldt una buena muestra de ello, aunque anticipado por otros autores franceses como Bernardin de Saint-Pierre, que en su Voyage a l'ile de France (1773) había empleado un estilo literario muy en consonancia con la exuberancia y la riqueza de la naturaleza tropical ${ }^{34}$. Grasset se sitúa en esta última línea, por cuanto en su obra abundan las enumeraciones y los calificativos, intentando crear un cierto nivel de expresividad que atraiga la atención de un lector, que, no lo olvidemos, debía pertenecer a sectores sociales con un nivel de instrucción medio.

Pero Grasset es deudor asimismo de toda una tradición literaria preocupada por acuñar la imagen de los pueblos no europeos, y que tuvo en la descripción de los habitantes americanos, como ya hemos señalado, su principal reto ${ }^{35}$. La percepción del otro cambia, abogándose por un "relativismo cultural" ya señalado hacía doscientos años por Montaigne: los amerindios son salvajes no porque sean inferiores a nosotros, sino porque viven una existencia más simple y pura ${ }^{36}$. En el siglo XVIII, desde el momento en que Bougainville arribara a las costas de Tahití y publicara sus impresiones en su Voyage autour du monde $(1771)^{37}$, este discurso se reactualiza, presentándonos la imagen feliz, despreocupada y gentil de los pobladores del Pacífico, residentes en una especie de paraíso terrenal, y que animaría las construcciones intelectuales de Rousseau y de Diderot (Supplement au voyage de Bougainville, 1772) ${ }^{38}$.

\footnotetext{
33 REYNAUD, Denis. Pour une théorie de la description au 18e siècle. Dixhhuitieme Siècle, 22, 1990.

34 PIMENTEL IGEA, Juan. Cuadros y escrituras de la naturaleza. Asclepio, LVI-2, 2004.

35 Una útil introducción en PAGDEN, Anthony, La caída del hombre.... op.cit.

36 MUTHU, Sankhar. Enlightenment versus empire. Princeton: U.P., 2003.

37 Sobre Bougainville, DUNMORE, John. Storms and dreams. Louis de Bougainville. Exisle Publishing, 2005. La imagen tópica de los tahitianos en CONNAUGHTON, Richard. Omai. The Prince who never was. Londres; Timewell Press, 2005.

38 GLENISTER ROBERTS, Kathleen. The Enlightenment noble Savage: Diderot's Tahiti and other Imaginary Locales. Alterity \& Narrative. Stories and the Negotiation of Western Identities, SUNY Press, 2008. Una breve descripción del Paraíso terrenal presentado por Bougainville y la visión ilustrada de la alteridad, en OUTRAM, Dorinda, La Ilustración.
} 


\section{Figura 4}

“Nobles Moderne et Ancien du Peru" en Grasseut de Saint-Saveur, Encyclopédie des

Voyages. Amérique

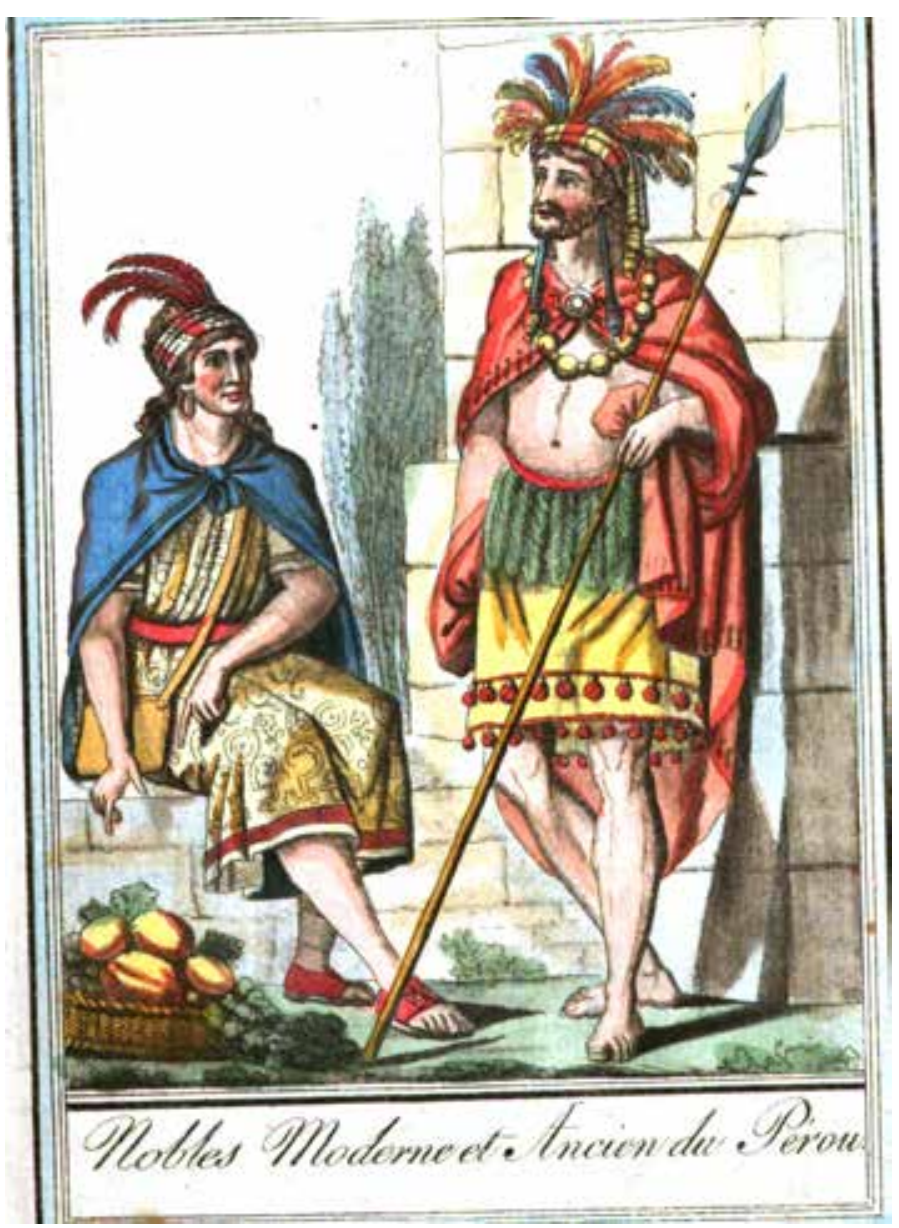

Al mismo tiempo, todavía no se habían publicado las obras de Blumenbach o de Petrus Camper, que abogaban por la existencia de unos determinados rasgos anatómicos responsables de las diferencias entre los seres humanos. Primaba por entonces la teoría monogenista, que atribuía las diferencias humanas a factores meramente externos como el clima (Montesquieu) o el color de la piel, derivado a su vez del nivel de insolación (Buffon), pero sin que ello supusiera una diferencia irreversible entre los distintos pobladores del planeta $^{39}$. Grasset es un fiel seguidor del monogenismo, por lo que son las costumbres y las

39 Una rápida panorámica de las teorías raciales del XVIII en MARTINEZ PESTANA, Paola. Des hommes noirs et non pas de negres: piel y raza en el siglo XVIII. Asclepio, LXIII, 1, 2011, PP. 39-64. 
prácticas las que vuelven o no civilizados a los hombres, y, en este sentido, la valoración moral de los pobladores americanos es muy variada: así, los iroqueses (figura 5$)^{40}$, prefieren la muerte a la esclavitud, la venganza es su pasión dominante, en ella concentran todos sus sentimientos, su silencio y su laconismo anuncian un pueblo frío y estúpido. Lo sacrifican todo a la amistad que es el lazo más sagrado, es un acuerdo de tenerlo todo en común, de combatir siempre juntos, cada iroqués tiene su amigo y solamente tiene uno, algunos viajeros injustos han querido ver un vicio en ello. La caza y la guerra llenan todos sus momentos, la caza tiene el objetivo de satisfacer sus necesidades, la guerra solamente tiene por objeto hacer prisioneros y masacrarlos. Los prisioneros son castigados con una muerte lenta y cruel. Es un pueblo grande y corajudo en medio de los suplicios, y se preparan a la muerte como a una fiesta. Es un pueblo laborioso, inteligente, vistoso, buen amigo, buen marido, buena madre.

Otras veces, por el contrario, fruto del desconocimiento de los distintos estadios de los niveles socioculturales y del ideal civilizatorio como elemento de máximo esplendor cultural, a los nativos se les presenta dominados por la apatía, muy en la línea con los defectos de los habitantes de los trópicos tan caros a la teoría de los climas de Montesquieu; así, según Grasset, los pobladores de la California se caracterizan por su indolencia e inconstancia, y es difícil encontrar una nación más estúpida y débil tanto en lo físico como en lo moral, aunque su misma estupidez les hace desconocer los vicios, por lo que no existen ni los robos ni las querellas (sic). En cuanto a los habitantes de la isla de Nutka, son descuidados, perezosos y enemigos de toda clase de ejercicio. No tienen ningún gusto, ninguna actividad, ninguna industria, ningún talento para la construcción de sus casas, la preparación de su comida o la navegación, aunque, eso sí, son infatigables en la construcción de sus armas (sic). Y los de la isla Príncipe Guillermo, los esquimales, son taciturnos, con los ojos fijos en la tierra y en una actitud reflexiva, fruto todo ello del país sombrío en el que habitan (sic).

O, en otras ocasiones, mostrando de nuevo la falta de civilidad de los grupos tribales o las bandas, en las costas del Pacífico americano se hace hincapié tan sólo en su ferocidad y en su barbarie: la Tierra de Fuego está poblada de hombres mil veces bárbaros, que se cubren con pinturas todas las partes del cuerpo, bien sea de color rojo o negro (sic). Los pobladores de Nutka, ya mencionados, son de natural guerrero, y, al contrario que los demás salvajes,

40 La visión del autor sobre los iroqueses ha llamado la atención de numerosos historiadores, entre ellos LIEBERSOHN, Harry. Aristocratic Encounters: European Travelers and North American Indians. Cambridge: University Press, 2001, pp. 13ss. 
no combaten en desorden o en masa, y no es el mero número el que consigue la victoria, ya que los combatientes de ambos bandos forman una especie de línea extendida y el combate se desarrolla hombre por hombre hasta la muerte, consistiendo la gloria del vencedor en capturar vivo a su enemigo (sic).

\section{Figura 5}

\section{“Guerrier Iroquois" en Grasseut de Saint-Saveur, Encyclopédie des Voyages. Amérique}

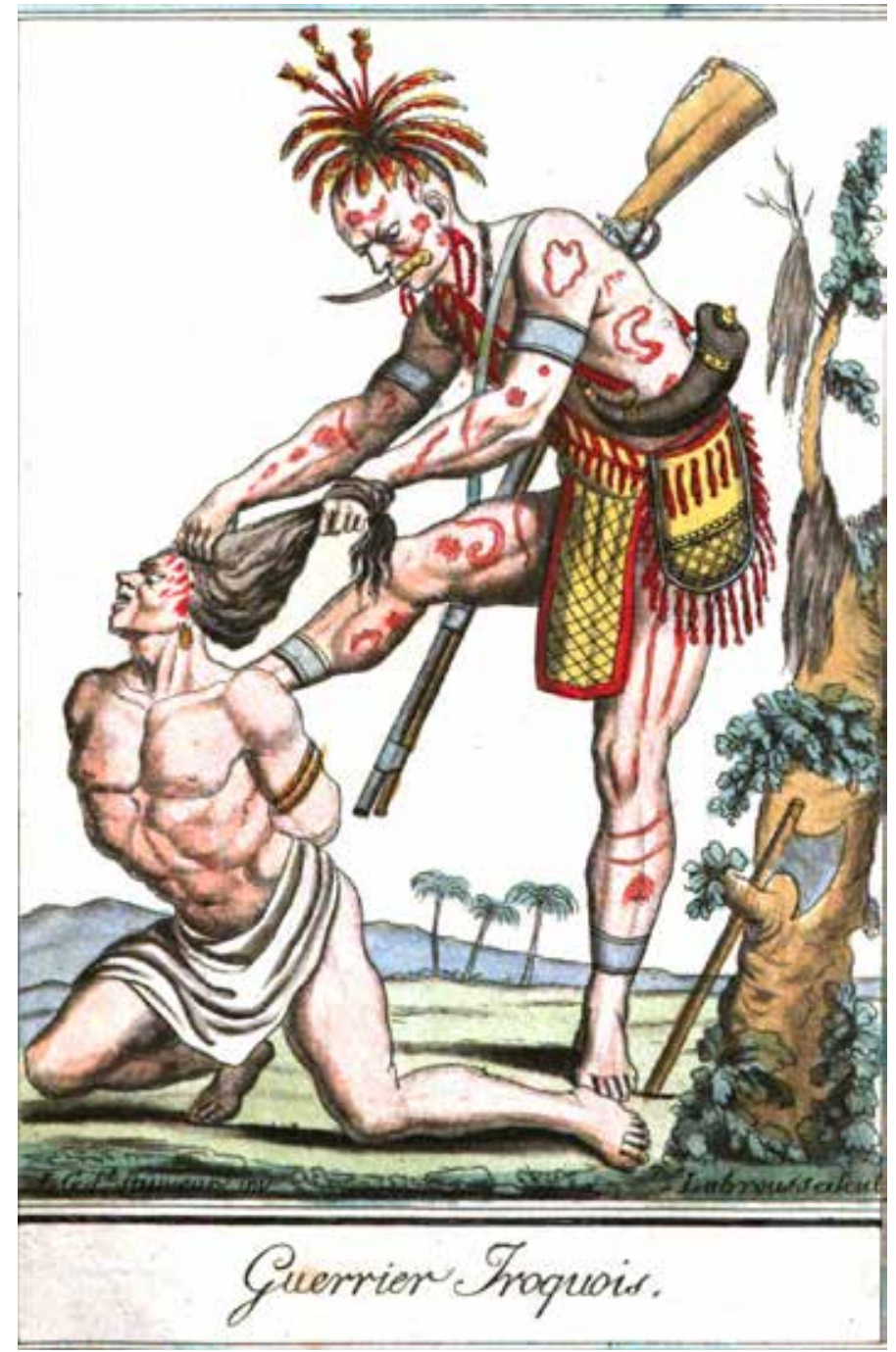

Grasset también se preocupa por plasmarnos una descripción de sus costumbres y de su estructura social, pero siempre dejando claro, como escribe en el "Discurso preliminar" de la Encyclopedie, que: "Europa es la madre de todas las artes, de todas las ciencias; es la patria de los grandes hombres. Conquistó América, $\gamma$ lo tiene bajo su yugo con tanta facilidad como el 
imperio Romano tenía Córcega y la Cerdeña ... hav que convenir que los europeos sobrepasan a otras naciones por su valentía tanto como por su conocimiento $\gamma$ su filosofía. Europa es el país del mundo donde se encuentra a físicos $\gamma$ astrónomos" ${ }^{41}$. Por lo tanto, como hombre de su tiempo, establece una clara diferencia entre aquellos pueblos y los europeos e incide especialmente en aquellas cuestiones que alejan a sus habitantes de cualquier proceso de civilidad, como pueden ser la falta de viviendas sólidas, de alimentos elaborados, de indumentaria sofisticada, de una organización política y social estructurada, o de creencias religiosas complejas. El autor, que desconoce la existencia de complejidades culturales, más allá de lo que suponía para él la "Civilización", por supuesto Europea, y la barbarie, escribe sobre las sociedades entre iguales poniendo de manifiesto su falta de conocimiento tanto en el mundo tecnológico como en el social: los patagones comen la carne cruda o secada al sol, no les gustan los licores fuertes, sus casas son tan simples como sus costumbres, adoran al sol, la luna y las estrellas, y son las mujeres las que se encargan de la educación de los hijos. Las casas de los fueguinos son tan simples como sus vestimentas. Sobre los pobladores de la península de California, no duda en utilizar el término de salvajes, aunque nos explica cómo viven "...divididos en familias que viven aisladas las unas de las otras sin ninguna forma de gobierno". Y los habitantes de la Guayana, cuya única preocupación es el descanso, olvidan por completo la religión, las leyes y la forma de gobierno.

Todo ello nos hace reflexionar sobre el interés de los viajeros filósofos que buscaban la realidad, tamizada por el elemento cultural propio, de las nuevas tierras y sus habitantes, y de la necesidad de una información más precisa y concreta, no sólo para los intereses políticos, sino también económicos. Es muy ilustrativo el discurso preliminar de Grasset, donde señala cómo los comerciantes, al conocer las costumbres, los hábitos, las formas de vestirse, y los productos de la tierra podrían llevar los artículos de su industria, y al mismo tiempo obtener de ellas los frutos más rentables. Luego la obra no sólo va a ser un conjunto de láminas más o menos estéticas, dirigida al gran público de la época, sino que pretende ser algo más, una fuente que sirva para el comercio, para informarse en general de aquellas tierras. Tal como señala en el Discurso preliminar, "El especulador encontrará por su parte en el vestuario de todos los pueblos, $\gamma$ en el conocimiento de sus hábitos, sus bases de operaciones: sabrá acerca de los objetos que puede llevar... y estas especulaciones no se basarán más ni en historias a menudo falsificados por intereses particulares'"'(p. 3).

41 BERNARD, Andrés. Jacques Grasset de Saint-Sauveur, Ou la mobilité culturelle au temps des Lumières. Interfaces Brasil /Canadá, nº 8, Rio Grande, 2008, p. 63. 


\section{LA REPRESENTACIÓN VISUAL}

Desde el mismo momento de la invención de la imprenta, la imagen fue, en muchas ocasiones, inseparable del libro, aunque la relación entre texto e imagen no fuese, ni mucho menos, unívoca. La imagen podía tener una función meramente ornamental, según la cual sería un mero añadido al texto, que, como mucho, transmitiría valores estéticos, emotivos, retóricos, etc., pero que son independientes de lo referido en el texto, en el sentido de que éste podría prescindir completamente de aquéllas sin verse modificado. Podía tener una función pedagógica, muy extendida en determinados períodos de la historia de la ciencia, como el siglo XVIII, cuando proliferaron manuales de filosofía e historia natural de carácter divulgativo para un público no especializado. Podía tratarse de una función descriptiva, según la cual la imagen, más o menos esquemática, representaría miméticamente los objetos y fenómenos del mundo tal y como se encuentran en la naturaleza, cumpliendo esta función los herbarios, atlas de anatomía y zoología, y en general todos los mapas. Y, finalmente, podía tratarse de una función explicativa, según la cual las imágenes intentan hacer comprensibles visualmente los razonamientos que subyacen a la explicación de un fenómeno ${ }^{42}$. Sea como fuere, las imágenes eran básicas en muchos de estos textos, que representaban realidades demasiado complejas como para poder fiarse tan sólo de las descripciones escritas ${ }^{43}$.

En el caso que nos ocupa, las imágenes ayudan sobremanera a la comprensión del texto, aunque no podemos perder de vista que, respondiendo a una clara estrategia editorial, se podía adquirir la obra única y exclusivamente para utilizar y enmarcar sus ilustraciones, incluidas en la misma de forma totalmente independiente de aquél. Aunque no tenemos constancia de cual podía ser el precio de estos volúmenes, y de si sus láminas podían o no ser asequibles a sectores sociales más o menos amplios, sí sabemos que había un público potencial para ello. De hecho, en la prensa dieciochesca se anunciaban con bastante frecuencia la venta de láminas sueltas, y podemos acudir a numerosos ejemplos españoles. El Diario de Madrid, por poner un caso, anunciaba la publicación de una colección de láminas de los especimenes existentes en el Real Gabinete de Historia Natural, comunicando en esta ocasión la venta de las estampas correspondientes al sapo volante y el faisán dorado de la China por el módico precio de cuatro reales ${ }^{44}$, lo que las hacía asequibles para el público de clase media. La fun-

42 GOMEZ LOPEZ, Susana, Modelos y representaciones visuales de la ciencia. Escritura e imagen. 1, $2005,92$.

43 DICKENSON, Victoria. Drawn from life. Science and Art in the Portrapal of the New World. University of Toronto Press, 1998.

44 Diario de Madrid, 21 de julio de 1788. 
ción de estas ilustraciones en los hogares parece bastante clara: era un motivo decorativo que permitía abrirse a los mundos del escapismo, la distancia y la ensoñación, y qué mejor camino para ello que las representaciones de pueblos o criaturas considerados exóticos.

Pero, como hemos comentado con anterioridad, Grasset, en una clara estrategia editorial, pretende ampliar su abanico clientelar e incluye a los comerciantes e incluso viajeros como futuros compradores de la obra justificándolo en el conocimiento que estas ilustraciones aportan sobre costumbres y enseres propios de la tierra en donde colocar los frutos de la industria. Ahora bien, es importante señalar que los modelos iconográficos empleados no son casuales, sino que están cuidadosamente seleccionados según unas tipologías muy concretas.

Podríamos establecer una doble diferenciación, sexual, y funcional. Cumpliendo el primer criterio, nos encontramos a treinta y dos varones, veintiuna mujeres y tres grupos mixtos. El esquema iconográfico más simple corresponde a una contraposición entre una figura masculina y otra femenina, definidos simplemente como homme ofemme, aunque en algunas ocasiones se emplea el término sauvage o sauvagesse, tal como sucede en los casos de la Bahía de Norton, Príncipe Guillermo, la Bahía de Hudson y Onalaska. Los varones tienen una edad indefinida, aunque la representación visual parece corresponder a una época de madurez, en tanto en el caso de las mujeres se pretende especificar algo más acudiendo en ciertas ocasiones a representaciones de filles, tal como sucede en la isla de Nutka. En el caso de las representaciones de carácter funcional, la única ocupación reconocida a las mujeres es la de bailarina (de hecho, dos de los tres grupos mixtos representan imágenes de danzantes), ya que, al fin y al cabo, ya durante esta época estaba consolidándose la idea rousseauniana de relegar a las mujeres a la esfera de lo doméstico. Los varones, por el contrario, pueden ser nobles, sacerdotes, o guerreros, bailarines o embajadores, lo que refleja una cierta estratificación social, pero de una gran simplicidad, por cuanto se limita al ejercicio del poder, la guerra o la religión, sin valorar en modo alguno la especialización profesional o el ejercicio de actividades productivas, si hacemos excepción de una ilustración representando a los habitantes de la Guayana "fabrican le rocou". La imagen que recibe el espectador es la de una sociedad con una clara división por sexos, y una estructura social bastante sencilla e incluso demoniza con el término de salvajes a aquellos cuyo nivel sociocultural es más simple, siendo éste el caso de los onas de Tierra de Fuego y los pobladores de la bahía de Hudson, o a aquéllos con unas costumbres, al entender del autor, más crueles (los iroqueses). Por otro lado, el discurso visual tiende a poner de relieve aquellos ámbitos geográficos en los cuales nos encontramos con una cierta complejidad desde el punto de vista étnico, distinguiendo 
así los mulatos en México, los mestizos y los españoles en Quito, y los negros y los blancos en Santo Domingo. Estas imágenes contribuyeron a la tradición americana de tipos y costumbres y de alguna manera contribuyeron a una prefiguración de la nueva idea de nación que se generaría en América tras la independencia ${ }^{45}$.

Si la tipología de las imágenes no es inocente en modo alguno, tampoco lo va a ser la forma de representación. El descubrimiento del continente americano había provocado ya en el siglo XVI la consolidación de un tipo iconográfico, a saber, el del salvaje ${ }^{46}$, que por otro lado bebía mucho de las fuentes visuales europeas, donde el salvaje peludo del medievo había sido sustituido en el siglo XVI por el salvaje de piel desnuda ${ }^{47}$. Dado la ausencia prácticamente total de imágenes en los libros publicados por los españoles, habida cuenta del fuerte secretismo oficial que rodeaba todo lo relativo a las nuevas tierras americanas y a las deficiencias de la industria editorial española ${ }^{48}$, serán los pueblos de allende los Pirineos, como ya hemos escrito con anterioridad, los responsables de la creación de esta iconografía.

Por otro lado, el retrato etnográfico, para ser creíble, necesita cumplir ciertas condiciones, siendo el principal objetivo la creación de una sensación de exotismo en el espectador, exotismo que se cumple, según Richard Brilliant ${ }^{49}$, prestando atención a detalles como la indumentaria, la apariencia personal o la raza, todo ello con una función tópica y no realista, lo que, por otro lado, responde claramente a la iconografía de las historias naturales del momento, que se vieron obligadas a emplear una tecnología de representación más analítica que naturalista ${ }^{50}$; aunque autores como Peter Mason hayan criticado estos argumentos, haciendo hincapié en que los artefactos presentados en estas imágenes responden claramente a su apariencia real, y son perfectamente identificables desde el punto de vista etnográfico ${ }^{51}$. Amén de todo ello, el retrato etnográfico enfatiza en la representación personal del individuo todo lo que se pueda aplicar al conjunto de su grupo, eliminando su

45 MAJLUfJ, Natalia, "Convención y descripción: Francisco "Pancho" Fierro (1807-1879) y la formación del costumbrismo peruano", Hueso Húmero, 39 (setiembre de 2001), pp. 3-44.

46 Un análisis de las primeras representaciones iconográficas en SAENZ LOPEZ, Sandra. Las primeras imágenes occidentales de los indígenas americanos: entre la tradición medieval y los inicios de la antropología moderna. Anales de Historia del Arte, 2011, pp. 463-481.

47 BARTRA, Roger. El salvaje en el espejo (México, FCE, 1992), y El salvaje artificial (México, UNAM, 1997).

48 PINO DIAZ, Fermín del. Texto y dibujo. La Historia indiana del jesuita Acosta y sus versiones alemanas con dibujos. Jahrbuch für Geschichte Lateinamerikas, 42, 2005.

49 BRILLIANT, Richard. Portraiture. Londres: Reaktion Books, 1991.

50 OGILVIE, Brian. The science of describing. Natural History in Renaissance Europe. University of Chicago Press, 2008, Pp. 193ss.

51 Cfr. MASON, Peter. Infelicities, Representations of the Exotic. Baltimore: The John Hopkins University Press, 1998. 
individualidad en beneficio de una representación homogénea al servicio de los intereses imperiales europeos ${ }^{52}$.

\section{Imágenes incluidas}

Perú. Nobles modernes et anciens. Femmes nobles peruviennes moderne et ancien. Guerries ancien et moderne. Ancien pretre. Paysans peruviens. Paysannes.

México. Topitzin. Guerrier. Esclave (mujer). Mulatre libre. Esclave (varón). Montagnard.

Santo Domingo. Negre et negresse. Bouquetieres (mujeres). Negresse et femme mulate. Blanchiseuses (mujeres). Negres se ballant au balon (varones). Danse de negres (varones y mujeres).

Quito. Espagnole. Indienne. Metive (mujer). Barbier indien. Paysan. Paysanne.

Guayana. Hommes. Femmes indiennes. Habitants de la Guyanne fabrican le rocou. Danseur et danseuse.

Iroqueses. Gran chef. Guerrier. Sauvage. Sauvagesse. Iroquois allant a la decouverte. Tongleur iroquois (varón).

Bahía de Hudson. Sauvage. Sauvagesse.

Acadios. Homme. Femme.

Patagones. Chef. Homme. Femme.

Terre de Feu. Sauvage. Sauvagesse. Pretre medecin.

California. Homme. Femme. Pretre medecin.

Nutka. Guerrier. Homme. Femme. Fille.

Bahía de Norton. Homme. Femme.

Príncipe Guillermo. Homme. Femme.

Onalaska. Homme. Femme.

Dado estos antecedentes, podríamos esbozar algunos tipos iconográficos, siendo evidente en todos ellos la influencia de la estética neoclásica. Así, el guerrero con referencias más o menos remotas al mundo clásico, como el Chef des Patagons (tehuelches meridionales)(figura 6), tocado de plumas (atributo de siempre relacionado con el continente americano), color de la piel blanco y barba, que parece llevar un instrumento musical con cascabeles y campanillas de metal, lo que implicaría una difusión cultural del contacto con los blancos. 
El guerrero semidesnudo, como el habitante de la tierra de Fuego (figura 7), con un arco y una flecha en la mano y la piel de color blanco. El homme de la Californie, con lanza en mano, vestido de pieles y tocado de plumas. El guerrero bárbaro, como el habitante de la isla de Nutka, con un garrote en la mano y la cabeza de su enemigo en el suelo, semidesnudo y con la cara pintada.

\section{Figura 6}

\section{“Chef des Patagons" en Grasseut de Saint-Saveur, Encyclopédie des Voyages. Amérique}

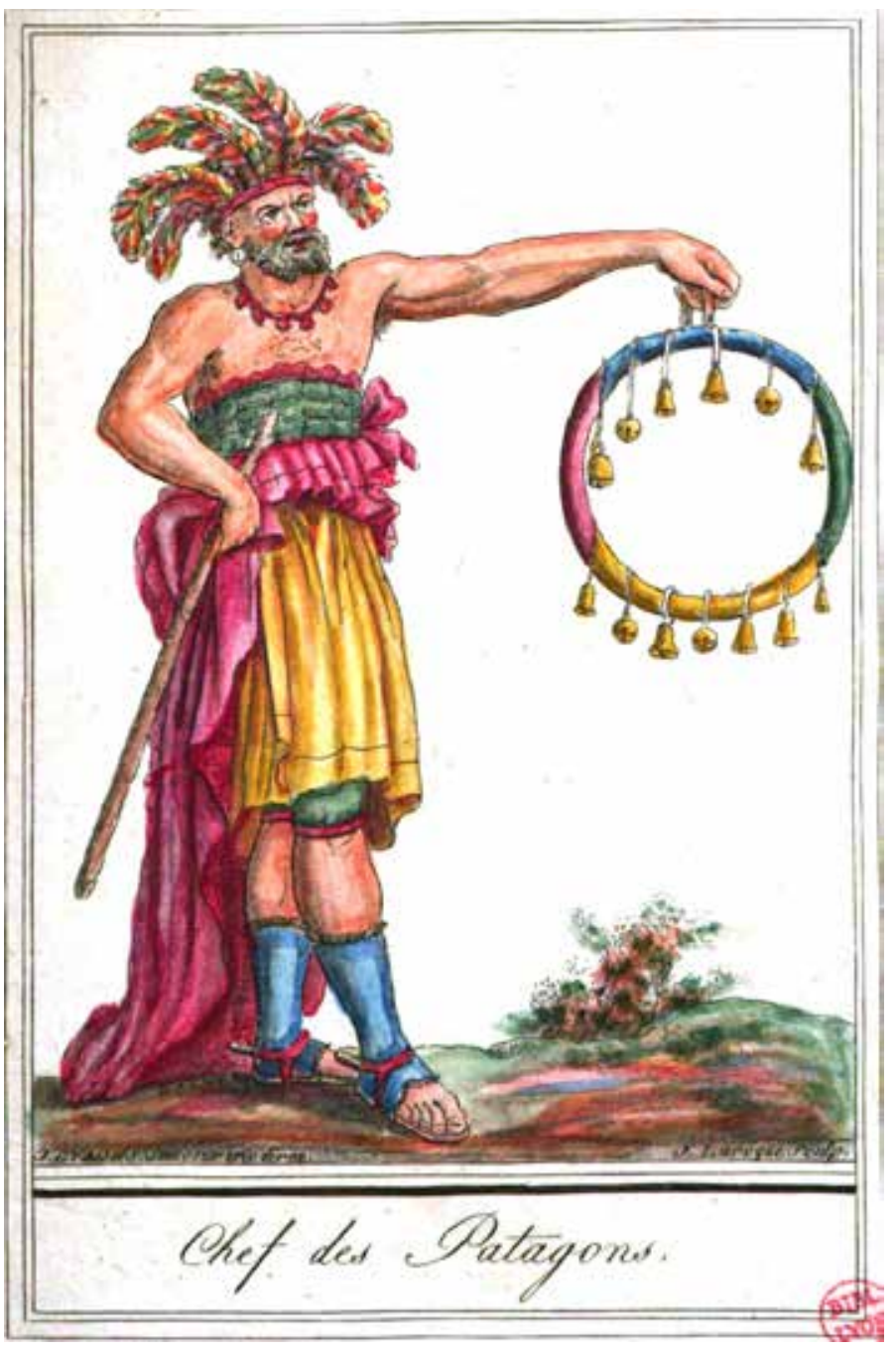

La mujer vestida con el niño en la mano, como la femme patagonne (figura 8), trasunto del tema del ángel de la guarda, en este caso de piel blanca y con las mejillas sonrojadas. La mujer desnuda de cintura para arriba, como la sauvagesse de la Terre de Feu, o la femme de la Californie (figura 9), con collares en el cuello y demás abalorios, y nuevamente de piel blanca. 


\section{Figura 7}

“Sauvage de la Terre de Feu” en Grasseut de Saint-Saveur, Encyclopédie des Voyages.

\section{Amérique}

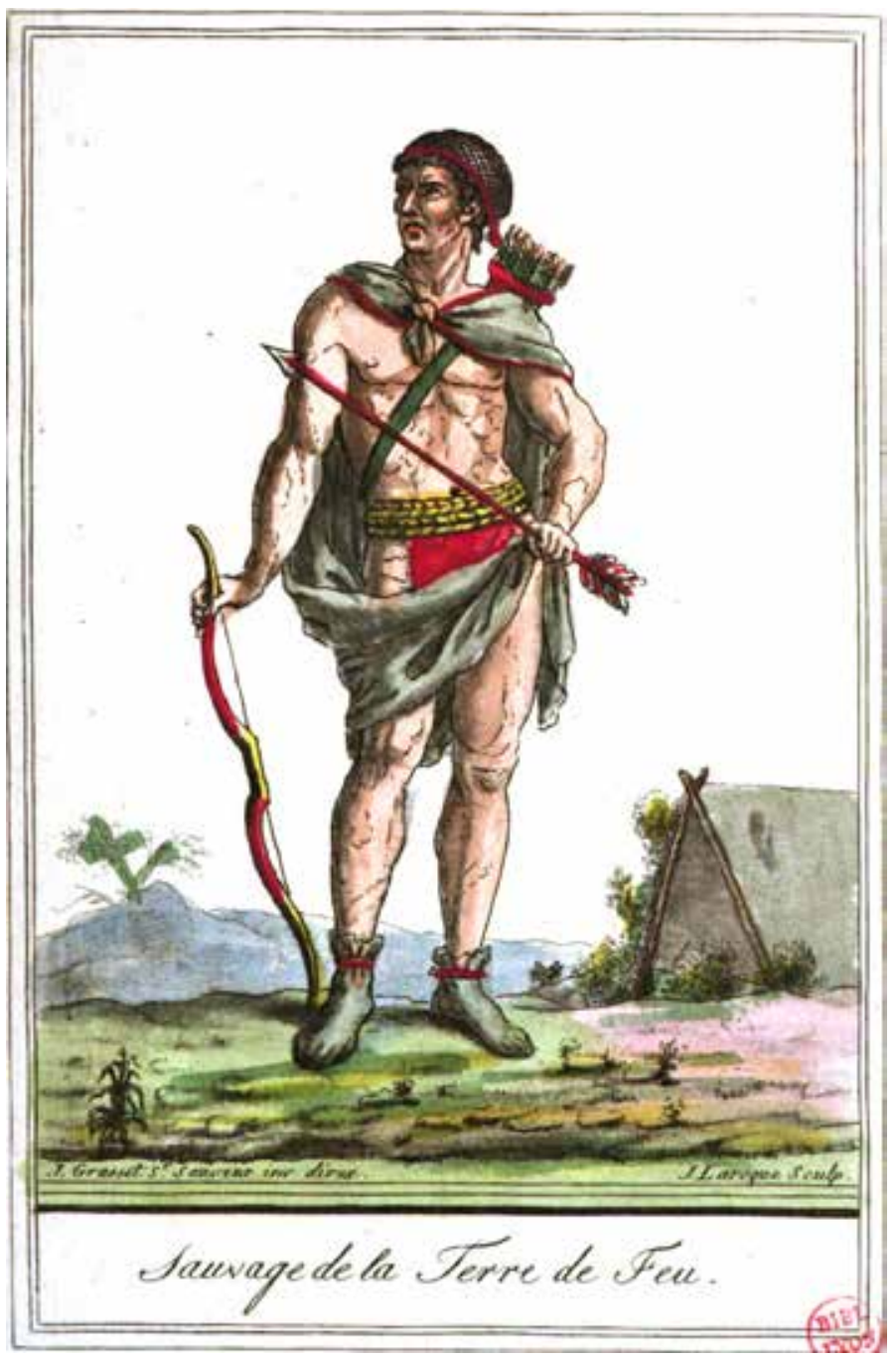

Tipos humanos de origen europeo, o que reflejan en su indumentaria una clara influencia europea, como la mujer acadia (figura 3), y la española (figura 2) y la mestiza de Quito. O bien de origen africano, caracterizado por el colorido y la exuberancia de sus ropajes, tal cual sucede en las representaciones de los pobladores de la isla de Santo Domingo (figuras 4 y 5 ).

La individualización de estos tipos etnográficos se pretende realizar por medio del ropaje, los adornos corporales y los peinados, aunque no sabemos el grado de su fidelidad al original. Se trata asimismo de imágenes absolutamente descontextualizadas de su medio, lo que es muy propio de muchas representaciones del momento, como las pinturas anima- 
lísticas ${ }^{53}$, y tan sólo en algunas ocasiones se incluyen fondos paisajísticos o de viviendas. Así, una rústica cabaña, aunque real, en la representación del sauvage de la Terre de Feu. O algunas plantas toscamente dibujadas en la imagen del Pretre Medecin de la Terre de Feu, que nos remite a la asociación entre botánica y medicina. O los aparejos de pesca que aparecen acompañando la representación de la Fille de Nootka. O el fondo, absolutamente irreal, de palmeras y tiendas de campaña de la mujer de la bahía de Norton. Otras veces nos encontramos con utensilios directamente relacionados con las costumbres de estas culturas, como el remo que porta el hombre de la isla de Nutka.

\section{Figura 8}

\section{“Femme Patagonne" en Grasseut de Saint-Saveur, Encyclopédie des Voyages. Amérique}

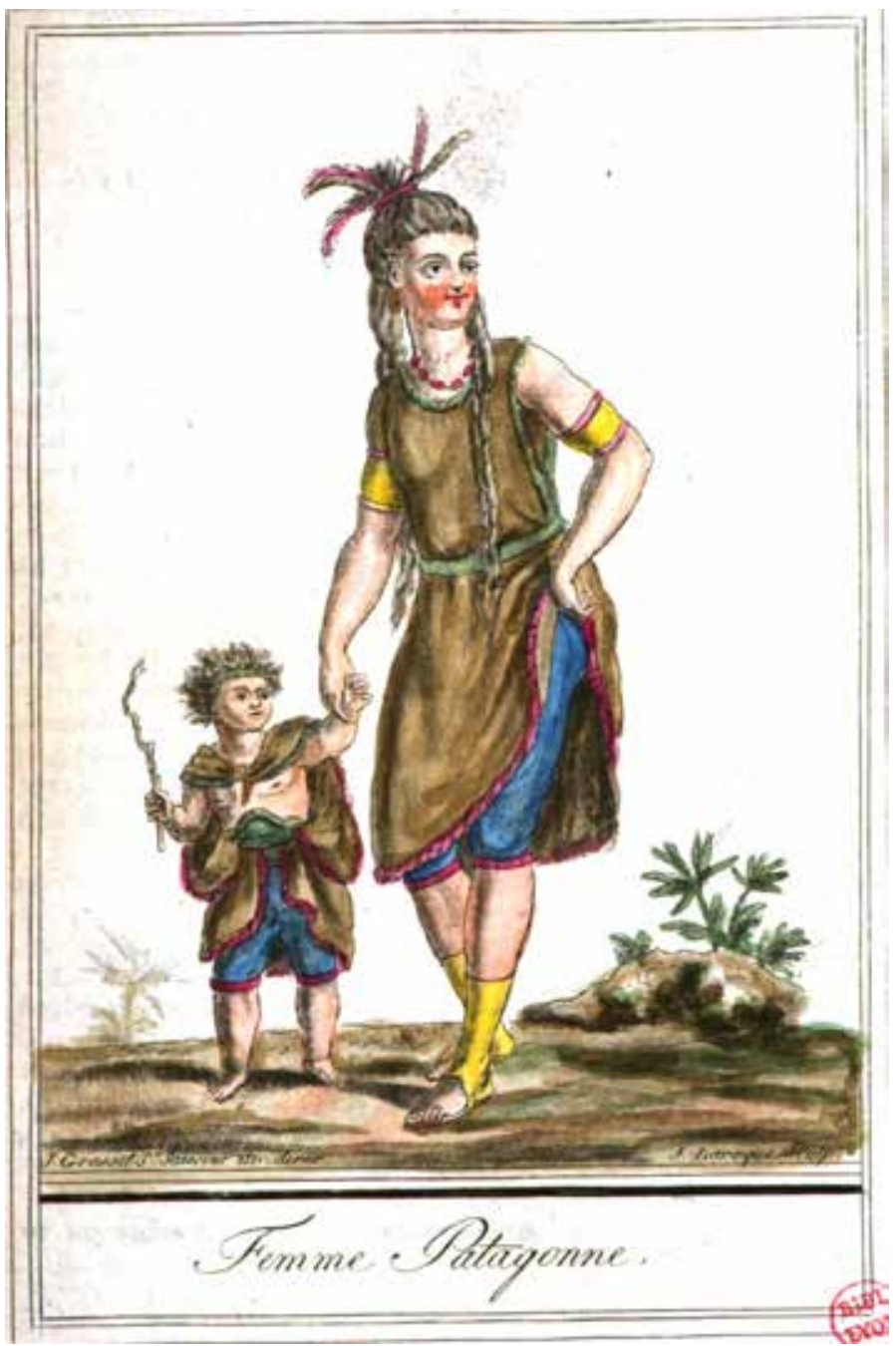

53 COWIE, Helen. Conquering Nature in Spain and its Empire 1750-1850. Manchester University Press, 2011. 


\section{Figura 9}

“Femme de la Californie" en Grasseut de Saint-Saveur, Encyclopédie des Voyages.

\section{Amérique}

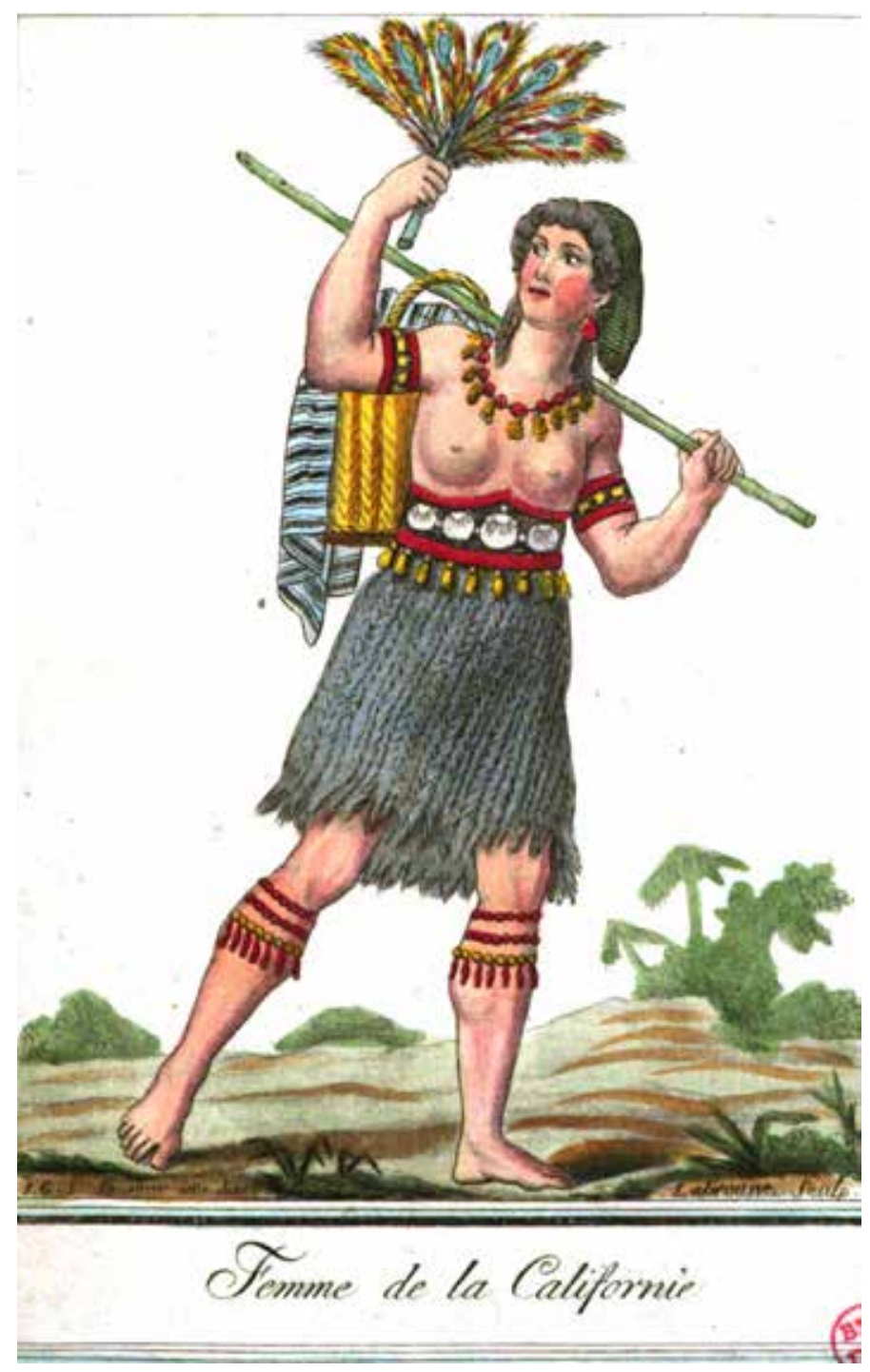

\section{CONCLUSIÓN}

La obra de Grasset no pretende reflejar un cuadro realista de los pobladores del continente americano, aunque él pretenda aumentar su nicho editorial dándole una cierta verosimilitud. Las descripciones literarias, a pesar de su vivacidad, son parciales, y más preocupadas por ofrecernos determinados tipos etnográficos que por proporcionarnos un relato medianamente completo de la estructura social y de las costumbres de todos estos pueblos. Por 
otro lado, las representaciones visuales son absolutamente tópicas, pretendiéndose crear una atmósfera de verismo utilizando elementos copiados de las descripciones de los expedicionarios como peinados, ropas, joyas o armas, sin ninguna intención naturalista, y sin conexión alguna entre el indígena y el medio que habita.

Pero su valor radica en su capacidad de crear tópicos, una obra barata como ésta, publicada en forma de cuadernillos sueltos, y con ilustraciones de una cierta belleza que podían ser utilizadas de manera totalmente independiente del texto (es decir, enmarcándolas y colgándolas de las paredes) debió alcanzar una cierta difusión, y los consumidores de este producto cultural acabarían adquiriendo la imagen del continente americano como la de un mundo lejano y distante. No se crea una realidad, pero sí un mundo de sueños, fantasía e imaginación. Al fin y al cabo, para muchos franceses de finales del XVIII, inmersos en pleno proceso revolucionario, era más que suficiente. 